\title{
125 years of geological research for society
}

\author{
Johnny Fredericia and Peter Gravesen
}

In 1888 the first geological survey in the Kingdom of Denmark was born as the Geological Survey of Denmark (DGU, Danmarks Geologiske Undersøgelse) and in 1946 the Geological Survey of Greenland (GGU, Grønlands Geologiske Undersøgelse) was established. Both surveys were located in Copenhagen and were amalgamated in 1995 to form the Geological Survey of Denmark and Greenland (GEUS).

This was a happy amalgamation for both surveys. Even though DGU and GGU had different backgrounds and different working areas the employees had a lot in common, and today GEUS continues DGU's and GGU's work, but in an integrated way with new synergies - so a stronger Survey has evolved. This was the reason for celebrating GEUS' 125th anniversary on 4 April 2013 and it also explains the logo with the years 1888 and 1946 to the left and 2013 to the right (Fig. 1). The event was celebrated with a series of lectures held by national and international geoscientists, a reception for invited guests and a gala night for GEUS staff and board.

\section{The Geological Survey of Denmark 1888-1995: geology for society}

The document shown in Fig. 2 is considered the birth certificate of the first geological survey in the Kingdom of Denmark: the Geological Survey of Denmark (DGU). The letter, dated 4 April 1888, grants the first Danish professor of geology J.F. Johnstrup from the Mineralogical Museum government funds to organise and start the geological mapping of

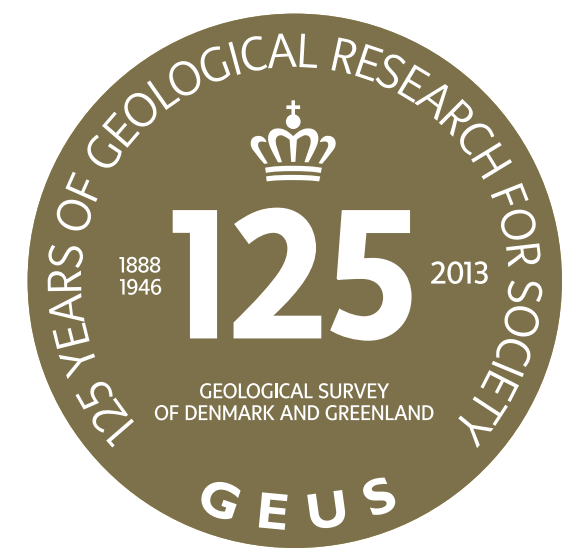

Fig. 1. GEUS' 125th anniversary logo.
Denmark. It was estimated to take 20 years and cost 20000 Danish kroner per year - corresponding to a little less than 1 million Euro per year in today's money.

Establishing a national geological survey was not an entirely new idea. Denmark lagged far behind its neighbours, who had started more than 25 years earlier - and it was one of the convincing arguments in Parliament at the time. The Geological Surveys of Norway and of Sweden were both established in 1858 (Fig. 3). The survey programmes in the

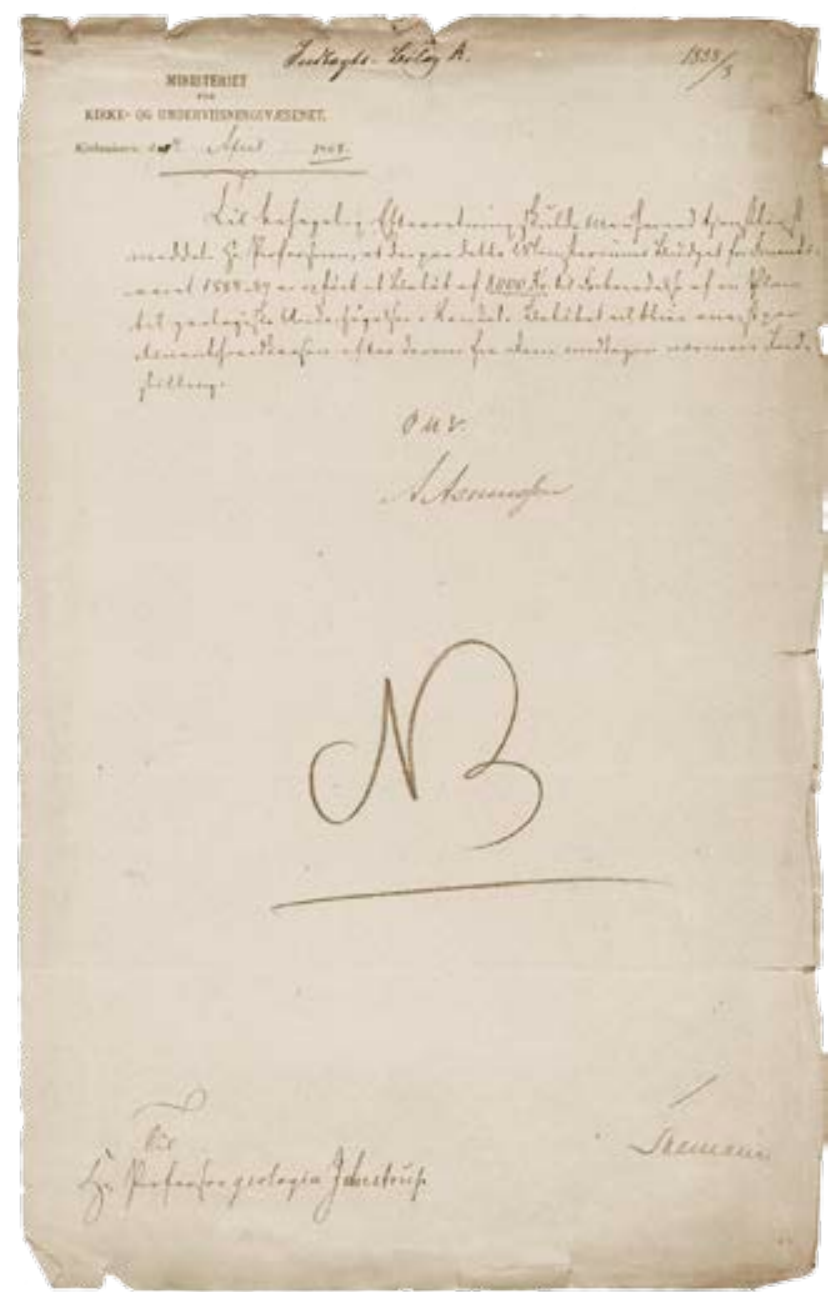

Fig. 2. The birth certificate of the Geological Survey of Denmark from 1888 granting funds to start geological mapping of Denmark. 


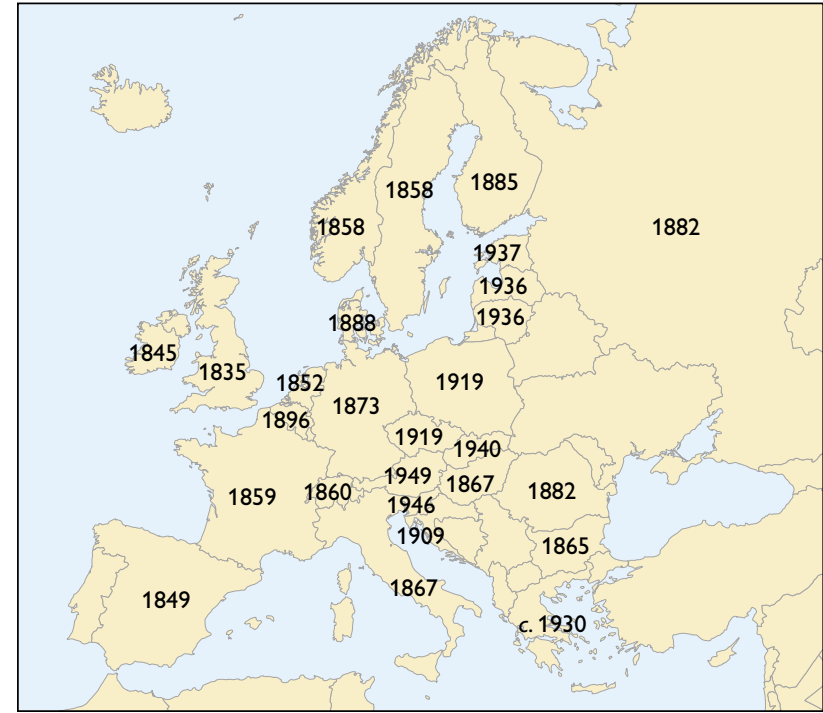

Fig. 3. The years of establishment of the European geological surveys (Påsse \& Kim-Andersson 2008).

other Nordic countries were also much more extensive than the modest beginnings in Denmark.
The purpose of the new Survey was to map the superficial deposits of the country to obtain knowledge about the important geological resources. At that time it was largely gravel, sand, clay, peat, brown coal and limestone, but also hydrogeology and the quality of agricultural soils were important. Knowledge of the superficial deposits was also of strategic importance for military operations. Figure 4 shows the first published map and one of the most recent. The same mapping units have been used throughout the years, which means that it is now possible to produce seamless digital maps. Mapping and investigating the Quaternary deposits in Denmark were core tasks for the Survey for more than a century, but over the years the systematic mapping of the superficial deposits has been overshadowed by large numbers of other tasks and commitments. A few examples are mentioned below.

Danish brown coal was previously widely used for heating, and exploration of brown-coal deposists in Jylland during World War I and up to World War II was a major task for DGU. The mapping of marl deposits was another important task for the young Survey; local marl was used to improve the agricultural soils in Denmark. Investigation of palaeoclimate and vegetation history based on macrofossils and pol-
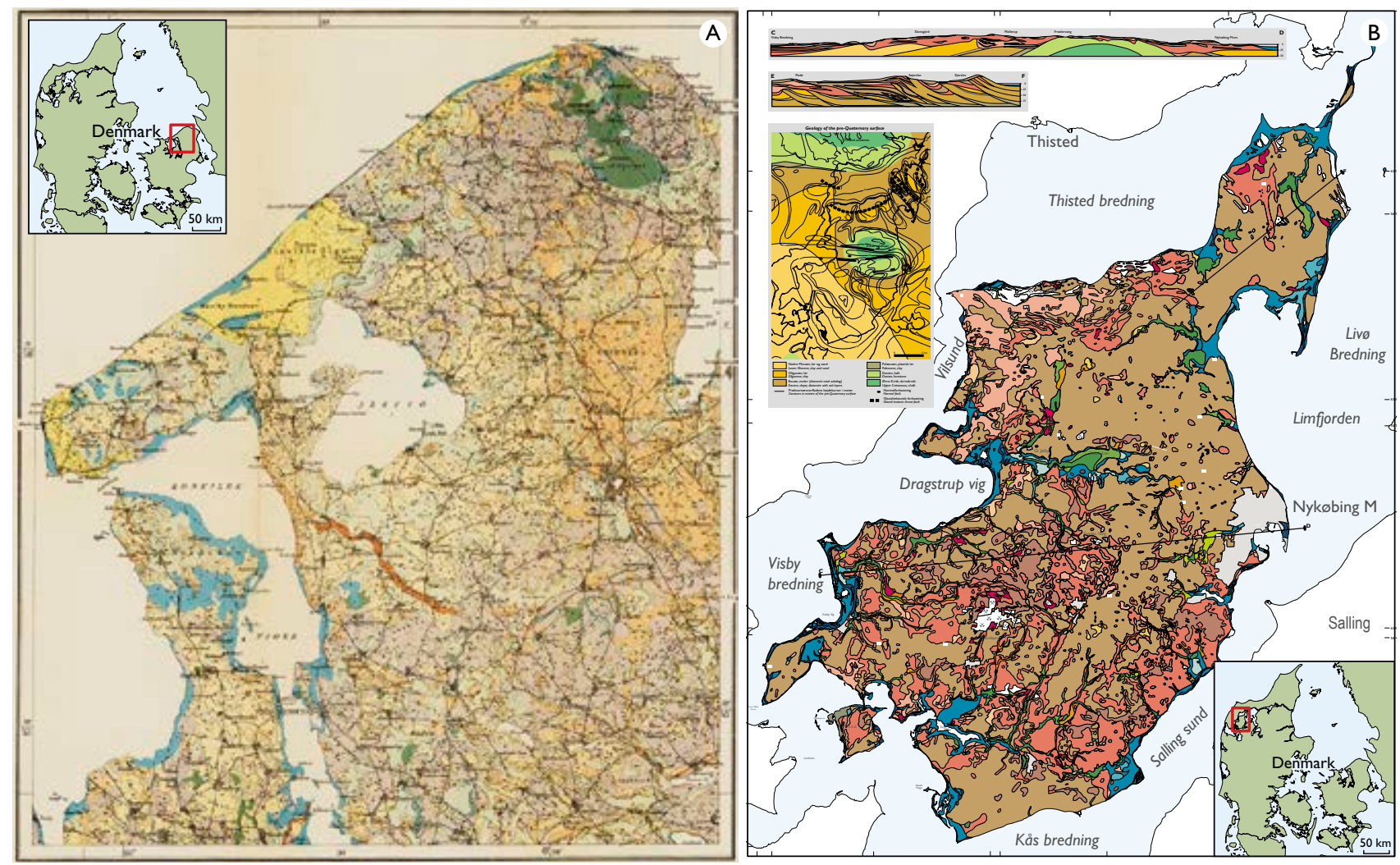

Fig. 4. Old and recent published maps of deposits at the terrain surface. The deposits are mainly of Quaternary age. A: Map covering parts of north-east Sjælland, published on a scale of 1:40 000 (Rørdam 1893). B: One of the latest maps covers the island of Mors in north-west Jylland, published on a scale of 1:50 000 (Pedersen \& Jakobsen 2012). 
Fig. 5. Excerpt from the seamless geological map of Greenland, published on a scale of 1:500 000 .

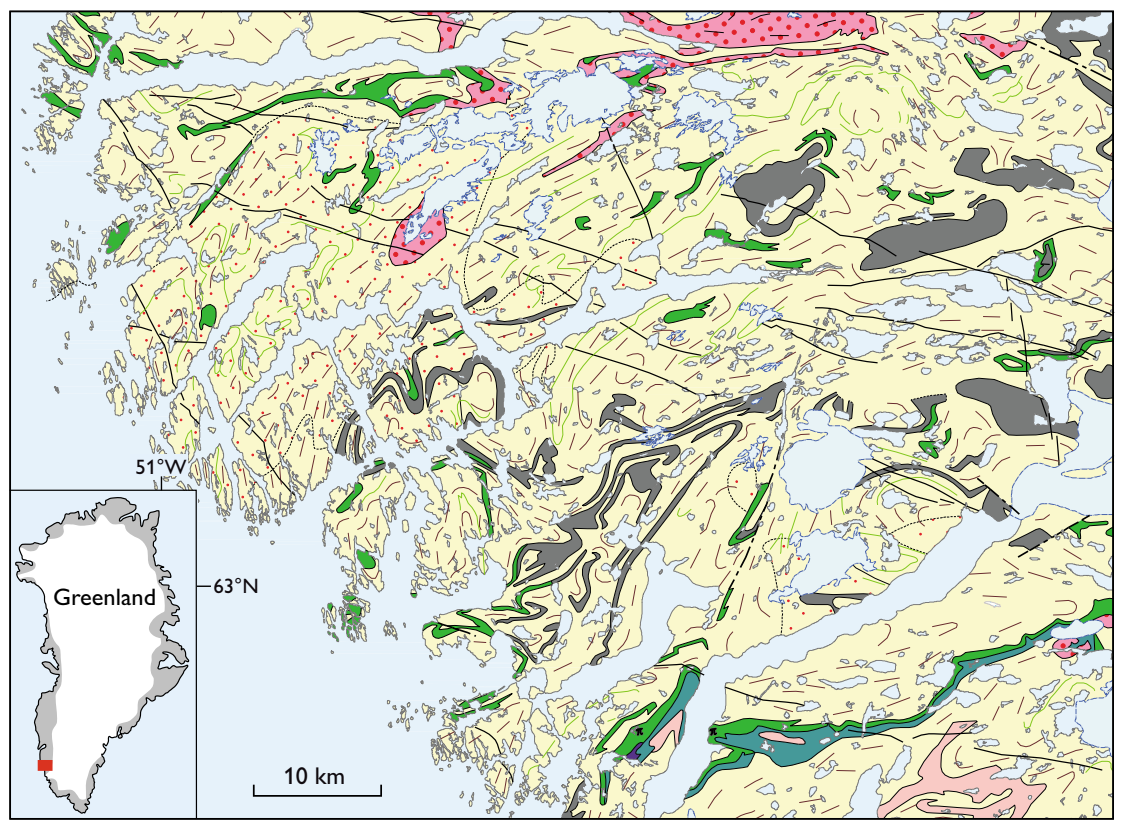

len from bog and lake sediments was another research area that started early at DGU. Danish water supply has been increasingly based on groundwater, and at an early stage DGU became engaged in solving quantity and quality problems for the public. In the 1970s and the 1980s the Survey was involved in groundwater mapping, and during this period the first large digital database in Denmark was established with borehole and groundwater data. Several projects concerning pollution of the groundwater with nitrate and pesticides were initiated in the 1980s and 1990s. Special attention was put into locating areas in Denmark which were sensitive to pesticide pollution and the Danish Pesticide Leaching Assessment Programme was established. Further nation-wide groundwater mapping was carried out in the early 2000s.

Interest in oil and gas exploration in Denmark began in 1935, and DGU became involved in aspects of this work, analysing borehole samples and interpreting seismic data. This work also resulted in the production of a series of thematic geological maps. The Samba database was established to store borehole data, geophysical surveys and reports. In the 1970s when it was suggested that radioactive waste from potential nuclear power plants in Denmark would be stored in Permian salt deposits, DGU demonstrated that salt diapirs were not suitable repositories. This was one of the reasons why Denmark decided in 1985 not to build nuclear power plants to produce electricity.

From 1888 to 1987 DGU was also the geological survey of the Faeroe Islands and mapped the volcanic rocks and superficial deposits of the islands. In addition, DGU carried out initial investigations to map potential oil reservoirs and conducted the first exploration boreholes.

\section{The Geological Survey of Greenland 1946-1995: a survey at the frontier}

After K.L. Giesecke's initial studies during the Napoleonic wars, other geological investigations and mineral exploration in Greenland began around 1850. From 1879 the expeditions were organised under the auspices of the Commission for Scientific Investigations in Greenland, often covering a wide range of natural science topics.

Geological investigations later became a key element in a number of expeditions to East Greenland under the leadership of Lauge Koch, funded by the Danish State. The expeditions began in 1926 and continued until the outbreak of World War II. They were resumed after the war and lasted until 1958.

In West Greenland geological mapping began in 1946 following the establishment of the Geological Survey of Greenland (GGU). The systematic mapping of Greenland was a tremendous task; Greenland is characterised by very limited infrastructure, and the size of the ice-free area is c. $410000 \mathrm{~km}^{2}$, nearly the size of Sweden.

As the knowledge of Greenland geology was initially very limited, the first years were spent on a reconnaissance study of the west coast to gain an impression of the geology involved. Systematic mapping on a scale of 1:100 000 began in the Ivittuut area in 1956. Ten years later it was realised that on that scale it would take a lifetime to cover Greenland, so the mapping was augmented with a series on 1:500 000 scale, first in West Greenland, then in East Greenland and in North Greenland from the 1970s (Figs 5, 6). The systematic 


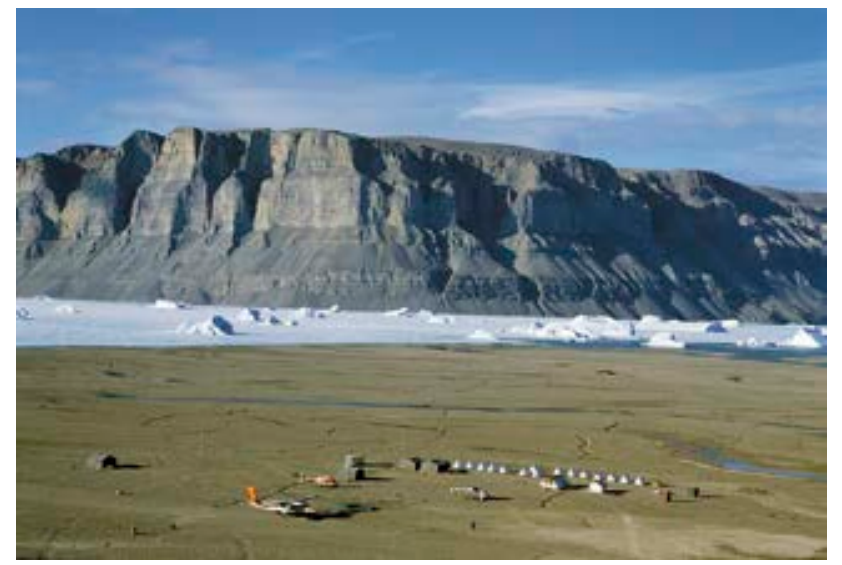

Fig. 6. Base camp in Warming Land in North Greenland in 1985. An Islandic Twin Otter aircraft and two Swiss helicopters are parked at the tent camp. The $600 \mathrm{~m}$ high cliffs in the background consist of Palaeozoic platform carbonates. Photograph: Jakob Lautrup.

mapping on 1:500 000 scale was completed in 40 years from 1964 to 2004.

Study and evaluation of mineral deposits of potential economic interest also took place along with the geological mapping. This was augmented in later years with airborne geophysical surveys with focus on mineral deposits. These studies, including geophysical investigations of offshore sedimentary basins, still continue, most recently in 2013 in South-East Greenland. In the 1960s, when Denmark was considering use of nuclear power, survey emphasis was placed on the discovery of radioactive minerals, as the Danish State had excluded radioactive minerals from commercial prospecting licences. Kvanefjeld in South Greenland was identified as a target in the 1960s and was extensively drilled (Fig. 7). Later stream sediment surveys throughout Greenland

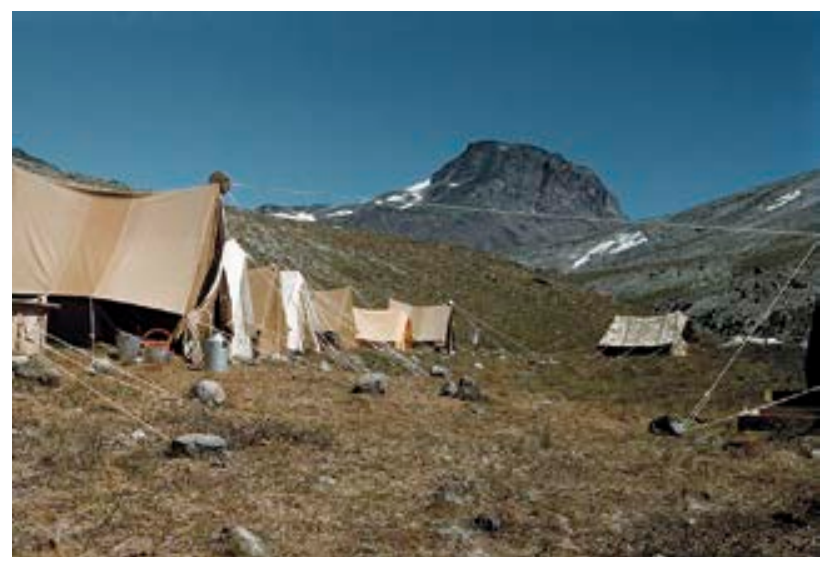

Fig. 7. Ten kilometres of core were drilled between 1958 and 1981 at Kvanefjeld in South Greenland to investigate the uranium contents. The drilling teams and geologists were camped. Photograph: Jan Bondam.

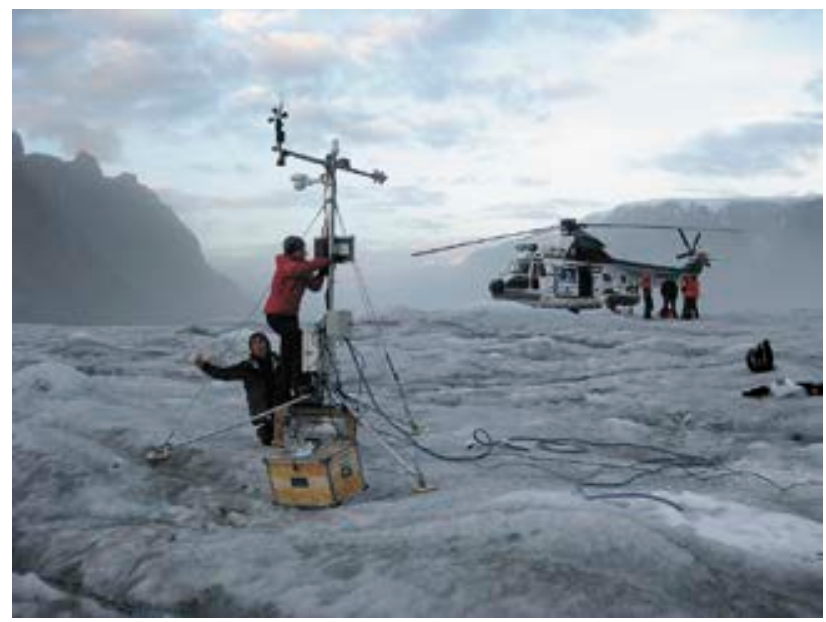

Fig. 8. Setting up an automatic weather station near the margin of the Greenland ice sheet. Photograph: Claus Heinberg.

have helped to locate gold and diamond provinces and indicate potential environments for base metals, platinum-group elements and rare-earth elements.

Following the discovery of oil in Alaska there was interest in the sedimentary basins offshore West Greenland and six licence blocks were issued in 1974. This entailed extensive detailed studies by the Survey of the adjacent onshore sedimentary areas. It was followed by active airborne and seaborne geophysical surveys and further study of onshore sedimentary basins in both West and East Greenland.

Greenland is dominated by a large ice sheet that influences the climate of the northern hemisphere. The run-off from this ice sheet was investigated in West Greenland prior to the building of hydroelectric plants, and the advances and retreats of its outlet glaciers have been followed and reconstructed backwards for decades. With the advent of climatic change the study of mass-balance models for the whole ice sheet has intensified, and in recent years GEUS has established a network of automatic weather stations which allows detailed monitoring of changes in the mass balance of the ice sheet (PROMICE; Fig. 8).

\section{The Geological Survey of Denmark and Greenland - the first challenges}

A reorganisation of the raw materials administration between Denmark and Greenland took place in 1995. As part of this reorganisation the future of GGU was discussed. The two directors, Martin Ghisler from GGU and Ole Winther Christensen from DGU, had the same vision and worked to amalgamate GGU and DGU and make a larger and stronger geological Survey (Fig. 9). Cooperation with geologists form the University of Copenhagen was strengthened by the estab- 

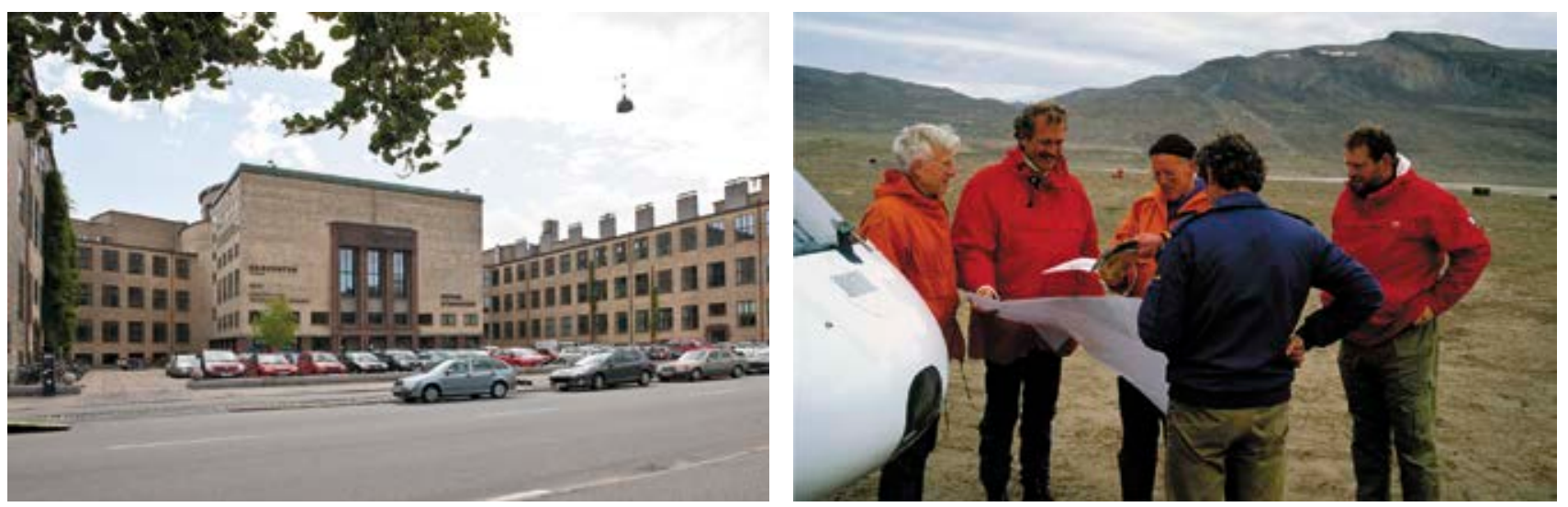

Fig. 9. DGU and GGU amalgamated in 1995. Left: The headquarters of GEUS at Øster Voldgade 10 in Copenhagen. Right: From the left, the former directors Martin Ghisler and Ole Winther Christensen in discussion with Niels Henriksen and Jens Morten Hansen on a field trip to North-East Greenland in 1995. Photographs: Jakob Lautrup.

lishment of Geocenter Copenhagen that comprised GEUS, the Geological Institute, the Geographical Institute and the Geological Museum of the University of Copenhagen. In 2007 an act for GEUS was passed by the Danish Parliament, and Geocenter Denmark was created, with a formalised collaboration between GEUS, the University of Copenhagen and the University of Aarhus. When GEUS celebrated its 125th anniversary, it was a celebration both for the Survey and for a strong alliance with the integrated Danish geoscience community. DGU and GGU had different beginnings and initially different schedules like trains meeting at a station, but we have stayed together and share the full story. Therefore it was logical to celebrate 125 years.

A book describing the history of GEUS: 'We - the people down-to-earth' (Vi de jordbundne) was published by GEUS in connection with the anniversary (Hansen \& Thomsen 2013). Its subtitle: 'Glimpses of GEUS over 125 years' (Glimt af GEUS gennem $125 \mathrm{ar}$ ). The book focuses on GEUS' role in society through the years and is partly based on earlier publications (Rasmussen 1988; Ellitsgaard-Rasmussen 1996; Fig. 10). The book does not give the complete story of GEUS, but provides an overview and glimpses of its history. It comprises special highlights, important changes of the institution and tells about people at GEUS in the past and at present. The book also includes a number of anecdotes that capture the work and social culture at GEUS.

\section{GEUS today}

GEUS is striving to be an international research organisation with the purpose of advising its users, the surrounding society in a broad sense. GEUS also develops and maintains national databanks with geological information on water, energy and mineral deposits and to some degree the climate, and is thus the geological memory of Danish society.

Being increasingly internationally orientated, GEUS has many partners in the Nordic countries, in the rest of Europe and farther afield. In particular, GEUS shares the vision of a much closer collaboration between the geological surveys of Europe, e.g. EuroGeoSurveys. A new regional cooperation between the surveys around the North Atlantic (NAG, Northeast Atlantic Geosciences) and increased cooperation between the Nordic countries have created important new avenues to develop our common role as surveys for a broader public.

However, other research organisations are also important partners for GEUS. For instance, GEUS has been partner in more than 75 European Union projects. GEUS also has a number of Memoranda of Understanding with countries outside the EU, and has been working in more than 30 countries outside Europe over the past 10 years. For example, GEUS has worked together with Vietnam for 17 years to build the country's capacity to develop their oil, gas and water resources.

GEUS also forms partnerships with other users of our knowledge, where we can contribute to growth in Denmark and Greenland. Water technology as a new business adventure is currently high on the political agenda, and GEUS strongly supports this effort. It is the intention to strenghten GEUS' unique cooperation with Copenhagen and Aarhus Universities in Geocenter Denmark, since it is a cornerstone in the future development of GEUS.

\section{GEUS in the future}

GEUS' goals for the future are expressed in the institution's strategy: GEUS strategi 2012. It stresses that GEUS 


\section{Vi, de jordbundne}

Glimt af GEUS gennem 125 âr (1888-2013)

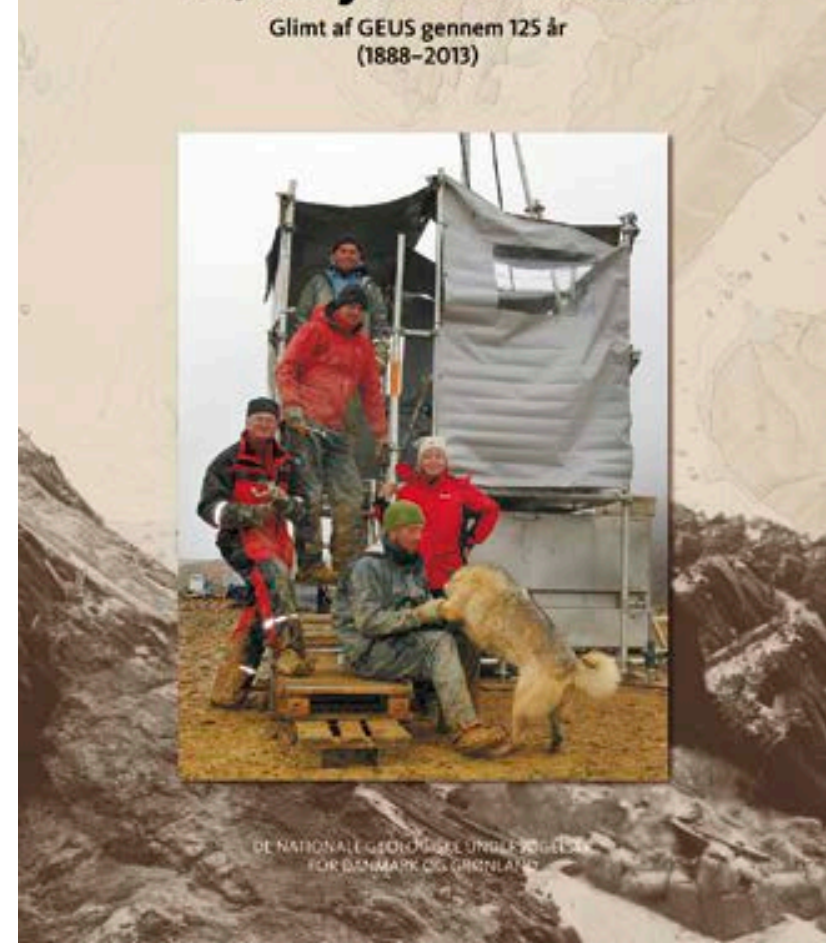

Fig. 10. The front cover of the anniversary book (Hansen \& Thomsen 2013) shows a GEUS drilling team in North-East Greenland. Photograph: Jørgen Bojesen-Koefoed.

will focus on increased cooperation and partnership - here and abroad, based on GEUS' nine strategic topics shown in Fig. 11. The strategic topics coincide with several of the grand challenges of this century: minerals, environment and climate change, water resources, energy supply and energy storage. These challenges match GEUS' own ambitions, and GEUS is ready to deal with the challenges where geoscience plays an important role. This reflects that GEUS is responsible and constantly trying to adjust itself to the changing needs of our society, which is becoming more and more internationally integrated.

Geological knowledge is of crucial importance to society in the 21 st century. GEUS will follow the changing demands from society and focus on the geological knowledge required so this can be developed to the benefit of Danish and international societies.

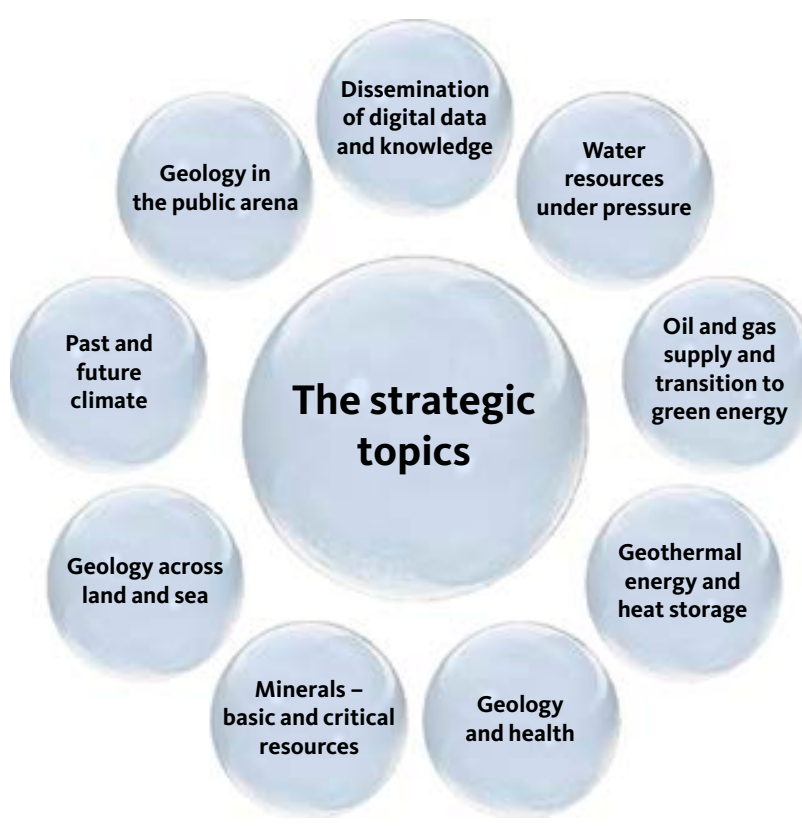

Fig. 11. The nine strategic topics from 'GEUS Strategy 2012 - basis for performance contract 2012-2015' coincide with several of the grand challenges of this century: minerals, environment and climate change, water resources and energy supply, and energy storage (GEUS 2012).

\section{References}

Ellitsgaard-Rasmussen, K. 1996: En stjerne fødes. Beretning om GGU's tilblivelse, 76 pp. Danmarks og Grønlands Geologiske Undersøgelse Rapport 1996/102, 76 pp.

GEUS 2012: GEUS strategy 2012, basis for performance conctract 2012-2015, 28 pp. Copenhagen: Geological Survey of Denmark and Greenland.

Hansen, J.M. \& Thomsen, H.H. (eds) 2013: Vi, de jordbundne. Glimt af GEUS gennem 125 år (1888-2013), 160 pp. Copenhagen: Geological Survey of Denmark and Greenland.

Pedersen, S.A.S. \& Jakobsen, P.R. 2012: Geological map of Denmark 1:50 000, Mors. Copenhagen: Geological Survey of Denmark and Greenland.

Påsse, T. \& Kim-Andersson, A. (eds) 2008: Sveriges Geologiska Undersökning. 150 år i samhällets tjänst, 185 pp. Uppsala: Sveriges Geologiska Undersökning.

Rasmussen, L.B. 1988: En jordisk krønike. Træk af DGU’s historie 18881998, 114 pp. Copenhagen: Danmarks Geologiske Undersøgelse.

Rørdam, K. 1893: Kortbladene Helsingør og Hillerød. Danmarks Geologiske Undersøgelse I. Række 1, 110 pp. 